\title{
Editorial: IZA Journal of Labor and Development
}

\author{
David Lam, Hartmut Lehmann, Jackline Wahba and Klaus F Zimmermann
}

Correspondence: izajold@iza.org Editors of the IZA Journal of Labor and Development
Dear Reader,

We are pleased to launch the IZA Journal of Labor \& Development (IZAJOLD), the first online journal entirely dedicated to labour markets in developing and transitional economies.

An ever more integrated world economy poses great challenges for working people in developing countries with respect to decent work, adjustment to restructuring and protection against unexpected shocks. The IZA Journal of Labor and Development will strive to become the main world-wide interlocutory platform for researchers who work on labor market issues in developing, emerging and transition countries. Having such a platform will be instrumental in better understanding how labor markets function in these countries, which in turn will help us to formulate policies that can meet these challenges.

The intersection of labor economics and development economics is one of the most exciting and important areas of current economic research. The IZAJOLD is designed to bridge these two fields, creating a forum for a wide range of innovative theoretical and empirical research linking labor and development. The mission of IZAJOLD is to publish high quality innovative research in all fields of labor economics in a development context both empirical and theoretical.

We are delighted that IZAJOLD is accessible through the SpringerOpen Access system, which means free permanent electronic access immediately upon publication. The editorial team of IZAJOLD will pursue prompt decision making and publication process.

We will strive with the help of our associate editors to ensure that IZAJOLD becomes a leading publication outlet in the field. We would like to thank Springer, members of the Editorial Board and current as well as future authors and referees in supporting us to achieve this goal.

David Lam

Hartmut Lehmann

Editors

Jackline Wahba

Managing Editor

Klaus F. Zimmermann

Editor-in-chief for the Journal Series

(c) 2012 Lam et al.; licensee Springer. This is an Open Access article distributed under the terms of the Creative Commons Attribution License (http://creativecommons.org/licenses/by/2.0), which permits unrestricted use, distribution, and reproduction in any medium, provided the original work is properly cited. 
doi:10.1186/2193-9020-1-1

Cite this article as: Lam et al.: Editorial: IZA Journal of Labor and Development. IZA Journal of Labor \& Development 2012 1:1

Submit your manuscript to a SpringerOpen ${ }^{\circ}$ journal and benefit from:

- Convenient online submission

- Rigorous peer review

- Immediate publication on acceptance

- Open access: articles freely available online

- High visibility within the field

Retaining the copyright to your article

Submit your next manuscript at $>$ springeropen.com 